\title{
UM RETRATO DO ROMANCE BRASLLEIRO CONTEMPORÂNEO DE AUTORIA FEMININA
}

\author{
A PORTRAIT OF CONTEMPORARY BRAZILIAN NOVELS BY FEMALE WRITERS
}

\section{RESUMO}

Nosso objetivo nesse artigo foi construir uma espécie de retrato do romance contemporâneo de autoria feminina, no qual destacamos as suas principais características temáticas, estéticas e ideológicas, matizadas de subversões feministas. O ponto de partida foi o mapeamento do modo de construção das personagens que integram um corpus constituído por 151 romances escritos por mulheres e publicados por três grandes editoras brasileiras entre os anos 2000 e 2015, realizado por meio da pesquisa "Literatura de autoria feminina brasileira contemporânea: escolhas inclusivas?”. A metodologia compreendeu o reconhecimento, a problematização e a interpretação de constantes que permeiam essa produção. $\mathrm{O}$ aporte teórico foi constituído a partir de uma perspectiva multidisciplinar que aborda o texto literário em suas interseções com o contexto sociocultural em que emerge e com teorias nascidas para pensar o mundo contemporâneo e suas manifestações artísticas, com ênfase na teoria crítica feminista.

Palavras-chave: Autoria feminina. Romance contemporâneo. Construção de personagens. Performances femininas. Subversões feministas.

\begin{abstract}
The aim of this study was to build a sort of portrait of female authorship in contemporary novels, in which we highlight their main thematic, aesthetical and ideological features, characterized as feminist subversions. The starting point was mapping the construction mode of characters that are part of 151 novels written by women and published by three prominent Brazilian publishing companies from 2000 to 2015 . This mapping was done according to the research "Literature by contemporary Brazilian female authors: inclusive choices?" The methodology comprised the recognition, problematization and interpretation of the constants that permeate such production. The theoretical framework was built through a multidisciplinary perspective that approaches literature in its intersections with the sociocultural context from which it emerges, and with theories that were devised to reflect upon the contemporary world and its artistic manifestations, with an emphasis on feminist critical theory.
\end{abstract}

Keywords: Female authorship. Contemporary novels. Characters construction. Female performances. Feminist subversions.

Lúcia Osana Zolin

Professora associada da Universidade Estadual de Maringá. E-mail: luciazolin@yahoo.com.br 


\section{Primeiras considerações}

A literatura de autoria feminina brasileira vem sendo amplamente debatida nos circuitos acadêmicos espalhados por todo o país, no âmbito de grupos de estudos e de programas de pós-graduação, resultando em uma vasta gama de produtos científicos, em forma de livros, de artigos científicos e de dissertações de mestrado e teses de doutorado. Trata-se de um interesse surgido na esteira das conquistas dos feminismos que inseriu a mulher, entre outros lugares, no mundo da literatura que legitimava, até então, apenas as presenças masculinas. As vozes historicamente silenciadas em nome da supremacia intelectual dos homens de Letras, se irrompem e, não sem muito esforço, vão ganhando espaço, de modo a fazer avultar a perspectiva sociocultural das mulheres, com sua multiplicidade de rostos, de interesses e de demandas.

É assim que, em meio aos heróis tradicionais que povoavam a literatura canônica e que ainda vem se propagando na grande literatura contemporânea, quase sempre do sexo masculino, vivenciando dilemas peculiares ao gênero masculino e desempenhando, igualmente, papeis sociais que lhes são peculiares, avultam também as personagens femininas que protagonizam as narrativas escritas por mulheres, narrando suas próprias histórias, trazendo a lume as questões que lhes povoam o imaginário, as angústias que lhes marcam o cotidiano e as identidades. E, desse modo, empreendem importantes fraturas nas representações femininas tradicionais das grandes narrativas acima referidas, calcadas no binômio natureza x cultura, indissociável da relação mulher/natureza. Nesse sentido, configuramse como importante instrumento de resistência à opressão secular da mulher que, embora já bastante contestada, ainda persiste escamoteada por entre práticas e discursos naturalizados na nossa cultura.

A pesquisa "Literatura de autoria feminina brasileira contemporânea: escolhas inclusivas?" que coordenamos na Universidade Estadual de Maringá, no decorrer dos últimos anos, com a preciosa ajuda de um entusiasmado grupo de estudantes e pesquisadores/as ${ }^{1}$ - agregando desde alunos/as de iniciação científica, de mestrado e doutorado, até egressos/as já inseridos/as no mercado de trabalho, desenvolvendo suas próprias pesquisas - teve por objetivo empreender um rigoroso mapeamento do modo de construção das personagens que integram um corpus constituído por 151 romances escritos por mulheres e publicados por três editoras (arroladas entre as mais importantes do país), Rocco, Record e Companhia das Letras, entre os anos 2000 e 2015. A equipe executora analisou 618 personagens, consideradas fundamentais para

1 Adrielle dos Santos Bergamasco (Pós-graduação); Alessandra Pajolla (Pós-graduação); Ana Maria Soares Zukoski (Pós-graduação); Andiara Maximiano de Moura (Pós-graduação); André Tardivo (Pósgraduação); Andressa Siqueira (Graduação); Fernanda Celestino (Graduação); Gabriela de Lourenço (Graduação); Gabriela Fonseca Tofanelo (Pós-graduação); Jairo José Campos da Costa (Pós-graduação); Joyce Muzi (Pós-graduação); Juliana Hanke (Graduação); Ligia de Amorin Neves (Pós-graduação); Marcela Betalini (Pós-graduação); Maristela Scremin Valério (Pós-graduação); Mirian Cardoso da Silva (Pós-graduação); Rafael Zeferino de Souza (Pós-graduação); Rosângela Aparecida Cardoso da Cruz (Pósgraduação); Tayza Nogueira Rossini (Pós-graduação); Wilma dos Santos Coqueiro (Pós-graduação). 
o desenrolar da trama dessas narrativas, cujas trajetórias foram ponderadas a partir de um questionário contendo 88 questões que, além de lhes deslindar detalhes da construção, se ocupam de detalhar o lugar de fala das autoras e a intensidade crítica com que cada obra aborda a temática em torno da qual se desenvolve. Os resultados foram implantados no software Sphinx - versão léxica que nos permitiu contabilizar, cruzar e interpretar os dados obtidos². Trata-se de um instrumento de "aferição" que embora pareça demasiado objetivo e, portanto, antagônico ao caráter escorregadio, sugestivo e subjetivo do texto literário, oferece-se como sinalizador do quadro geral das representações de gênero, abrindo nichos para o debate de ideias.

$\mathrm{Na}$ presente oportunidade, nosso objetivo é delinear - por meio da interpretação de dados quantitativos obtidos na pesquisa, bem como da abordagem do modo de desenvolvimento das principais temáticas - uma espécie de retrato do romance brasileiro contemporâneo de autoria feminina que recebe a chancela dessas casas editoriais de prestígio e, portanto, a validação dos mesmos no campo literário brasileiro, garantindo-lhes a visibilidade junto a livreiros, críticos e leitores. A metodologia compreende o reconhecimento, a problematização e a interpretação de constantes que permeiam essa produção. O aporte teórico está constituído a partir de uma perspectiva multidisciplinar que aborda o texto literário em suas interseções com o contexto sociocultural em que emerge e com teorias nascidas para pensar o mundo contemporâneo e suas manifestações artísticas, com ênfase na teoria crítica feminista.

\section{Pra início de conversa: quem são as escritoras desses romances?}

Se é bem verdade, como nos ensina Djamila Ribeiro (2019), que "todas as pessoas possuem lugares de fala” (p. 85), e que a localização social dos sujeitos e dos grupos socioculturais a que pertencem lhes impacta a visão de mundo, não é inócuo explicitarmos de que lugar falam as autoras dos romances aqui considerados. Isso porque elas constituem um seleto grupo de mulheres que, a despeito das interdições de gênero, conseguiram transpor os altos muros de importantes casas editoriais e mesclar suas vozes dissonantes, femininas que são, às vozes masculinas hegemônicas. Sim, mesmo antes de perscrutarmos os caminhos por elas percorridos, bem como as escolhas que fizeram ao se desincumbirem da tarefa de representar outras mulheres na arte que engendram, sabemos de antemão que são vozes dissonantes. Isso porque, muito provavelmente, não lhes seria possível falar em uníssono com as vozes masculinas - tão confortavelmente instaladas no mundo das Letras - sendo elas mulheres e, como tal, constituintes de uma casta de seres humanos historicamente silenciados e oprimidos. Mais que isso, cerceados em sua humanidade, já que, até

2 Metodologia desenvolvida por Regina Dalcastagnè (2005), na pesquisa "A personagem do romance brasileiro contemporâneo - 1990-2004" 
há pouco tempo, não era permitido, àquelas que vieram antes, falar, tampouco representar e, portanto, construir a subjetividade a partir de sua própria perspectiva.

Em relação ao conjunto de escritoras aqui considerado - constituído por noventa e uma (91) mulheres que juntas escreveram os cento e cinquenta e um (151) romances analisados na amostra -, não se pode deixar de considerar que ocupa um lugar favorável na nossa sociedade.

Trata-se de mulheres brancas (88 delas ou 96,7\%), predominantemente maduras $(37,4 \%$ tem mais de 50 anos, outros quase $40 \%$ têm mais de 70 anos), moradoras de grandes centros urbanos do Brasil (69,9\% no eixo Rio de Janeiro-São Paulo) e do exterior. Quanto à ocupação, além de se identificarem como escritoras profissionais $(86,8 \%)$, elas têm formação e/ou desempenham outras importantes funções no meio em que se inserem, como a de jornalistas/comunicadoras (30,7\%), professoras/pesquisadoras $(24,1 \%)$, entre as mais recorrentes, mas também muitas outras de prestígio, caso das artistas de áreas diversas, das roteiristas e produtoras de arte, das tradutoras, filósofas, psicanalistas, etc.

No limite, essas escritoras integram a chamada elite intelectual e a etnia hegemônica brasileiras, além de se situarem nos estratos socioeconômicos mais elevados dentre aqueles utilizados pelo IBGE para classificar a população do país. Não nos parece, portanto, casual o fato de serem essas mulheres, consideradas face ao recorte sociocultural que representam, as primeiras a adentrarem as grandes casas editoriais brasileiras, e não outras que se encontram à margem desses meios. Ainda que, muito provavelmente, para alcançarem esse patamar, tenham tido que superar inúmeros obstáculos - e não nos compete aqui entrar no mérito das agruras que, sabe-se lá, viram-se obrigadas a enfrentar para ocupar o lugar favorável que ocupam -, é certo que tiveram mais oportunidades que outras mulheres situadas fora desse circuito.

Sendo o campo literário um lugar de disputas pelo direito à expressão, em que avultam toda sorte de cerceamentos às vozes dissonantes, não há que se estigmatizarem essas escritoras por serem quem são, ou por falarem a partir da perspectiva de mulheres brancas, cultas, bem situadas socialmente. Importa salientar, antes de tudo, que, num espaço extremamente inóspito às perspectivas socioculturais das mulheres, há que se comemorar a inserção dessas vozes femininas aí. Isso, sem perder de vista a necessidade de se ampliar o escopo de perspectivas, a exemplo do que têm feito algumas editoras de menor porte e alcance mercadológico, as quais, progressivamente, vêm se especializando em colocar luz em vozes e identidades até então negligenciadas em favor da imagem de sujeitos supostamente universalistas. Afinal, todo mundo tem lugar de fala, de modo que, como bem esclarece Ribeiro (2019), a propósito da importância e da necessidade de a história da escravidão brasileira ser contada da perspectiva dos povos escravizados,

pessoas negras vão experienciar racismo do lugar de quem é objeto dessa opressão, do lugar que restringe oportunidades por conta desse sistema de opressão. Pessoas brancas vão experienciar 
do lugar de quem se beneficia dessa mesma opressão. Logo ambos os grupos podem e devem discutir essas questões, mas falarão de lugares distintos (p. 85).

\section{Das previsibilidades: sexo, faixa etária, posição na narrativa \& caracterização geral das personagens}

Sendo as escritoras quem são, não há que causar estranhamento o fato de $56,7 \%$ das personagens que integram os romances analisados (351 de um total de 618) serem femininas. Tampouco parece estranha a constatação de que, quando isolamos os/as protagonistas (208), a maioria é feminina (138 ou 66,4\%); e, sendo assim, também não foge às nossas expectativas de pesquisadoras/es a informação de que, dentre os/as protagonistas que acumulam a função de narrar a própria história, $65 \%$ ou 63 são igualmente femininas. Isso implica dizer que não só a perspectiva da qual derivam essas narrativas, personagens e tramas é feminina, como também é majoritariamente feminina as perspectivas representadas. Mesmo quando essas escritoras colocam em cena sujeitos masculinos narrando seus próprios dramas (34\% ou 33 narradores), não se pode perder de vista que o olhar a partir do qual derivam tais masculinidades é o da mulher escritora - um convite para o escrutínio da imagem masculina que lhes preenche o imaginário.

Dalcastagnè (2005), em ensaio em que analisa a personagem no romance brasileiro contemporâneo, levanta a hipótese de que "a maior familiaridade com uma perspectiva social determinada leva as mulheres a criarem mais personagens femininas e os homens, mais personagens masculinas” (p. 25), além disso, salienta que "aqueles que assumem a voz na narrativa tendem a compartilhar as características dos autores dos romances” (p. 48). Essa tendência de autorrepresentação parece consistir na motivação de algumas das principais características das personagens aqui analisadas. Estando boa parte das escritoras com mais de 50 anos $(37,4 \%)$ e outras tantas com mais de 70 anos (40\%), os números apresentados na tabela abaixo parecem coerentes com suas perspectivas de mulheres adultas, algumas já na chamada maturidade e outras na velhice, cujos horizontes lhes foram sendo dados não apenas pela própria vivência, mas também pelas experiências adquiridas nos cuidados dispensados aos mais vulneráveis, quase sempre, a cargo das mulheres.

É assim que quase metade das protagonistas da amostra é representada na idade adulta, aqui considerada como sendo uma fase de maturidade ou de transição para a maturidade, um momento propício para a reflexão acerca de importantes questões que ocupam o imaginário da mulher contemporânea. Questões essas que podem ser acessadas por meio do escrutínio das temáticas predominantes nesse corpus, tarefa a que nos propomos realizar em outra oportunidade. Entretanto, não nos parece insignificante a concentração de protagonistas femininas cujas trajetórias abrangem múltiplas idades (caso dos romances de formação - quase 9\%) ou atravessa 
mais de uma fase da vida (caso dos romances de filiação - cerca de 6\% -, entre outros). Mas o destaque vai para a protagonista idosa (13\% ou 18). Embora seja um número aparentemente inexpressivo, quando consideramos que, na literatura em geral, o protagonismo feminino não é uma tendência ${ }^{3}$, tampouco o é o de mulheres idosas, $13 \%$ nos parece um percentual bem significativo. São dezoito protagonistas com mais de sessenta anos, cujos dramas são narrados em primeira pessoa ou estão na mira de narradores oniscientes, quebrando o silêncio que em torno deles paira no universo literário. No lugar do apagamento da perspectiva da mulher idosa ou da cristalização da associação entre velhice e invalidez (física e intelectual), a problematização de seus dramas nascidos da dupla vulnerabilidade (mulheres e idosas); e também do modo como driblam os significados culturais do "velhismo", que, segundo Barbosa (2003), "equiparam-se a outros ismos como racismo, classismo e machismo" (p. 10).

Também nos parece ocupar o eixo das previsibilidades, tendo em vista o espelhamento de identidades entre escritoras e as protagonistas, o fato de mais da metade das personagens $(52,2 \%)$ ser construída de tal modo a deixar evidenciada a cor branca de sua pele. Outras 34,4\%, apesar não carregarem indícios explícitos de suas características étnicas, a ausência mesma de referências a preconceito racial e/ou a traços culturais típicos de outras etnias em suas trajetórias, levam o/a pesquisador/a a lhes inferir a branquidade ${ }^{4}$, numa espécie de reforço, seja ele consciente ou não, do estereótipo da identidade racial branca como sendo a do ser humano ideal, o parâmetro de todas as coisas nas sociedades alicerçadas na hierarquia racial. Se assim entendermos, teríamos $86,6 \%$ de personagens brancas, o que, embora não replique a diversidade étnica brasileira, condiz com a perspectiva de onde emana o discurso.

Todavia, $13,5 \%$ das personagens, um número pequeno, mas não insignificante, sinalizam a existência de grupos étnicos marginalizados, cuja presença é ofuscada na nossa cultura. Trata-se de um esforço vislumbrado em um pequeno conjunto dentre os romances que constituem o corpus da pesquisa, visivelmente empenhado em promover-lhes a visibilidade.

A despeito dos pequenos nichos de diversidade que se vão apresentando aqui e acolá, por entre os números levantados na pesquisa, outros marcadores relacionados à aparência e aos demais atributos das personagens vão emergindo condizentes não só com o lugar de fala desse conjunto de escritoras, mas também com um certo retrato que, aos poucos, vai sendo desenhado do perfil populacional que se encontra na mira de seus horizontes.

Falamos, em um primeiro momento, do conteúdo semântico dos adjetivos arrolados pela equipe executora da pesquisa para caracterizar cada uma das

3 Cf. Dalcastagnè (2005), menos de 30\% dos romances brasileiros contemporâneos da amostra analisada são protagonizados por mulheres.

4 O conceito, segundo Piza (2005), remete a uma perspectiva teórica das ciências sociais empenhada em oferecer respostas para o combate do privilégio do branco, tido como ser humano ideal, modelo cultural e normativo, através de uma política antirracista. Segundo a teórica, a "branquitude não diz respeito aos discursos ingênuos que afirmam: 'somos todos iguais perante Deus, ou perante as leis' ao contrário, reconhece que 'alguns são mais iguais do que os outros' e reverte o processo de se situar no espaço dos mais iguais para reivindicar a igualdade plena e de fato, para todos” (PIZA, 2005, p. o7). 
personagens em foco. Sem, obviamente, perdermos de vista de que a estratégia implica inferência e, portanto, uma visada subjetiva por parte do/a pesquisador/a. Isso não significa, todavia, que os dados devam ser colocados sob suspeita, antes entendidos a partir de sua especificidade.

Foram arrolados 1670 adjetivos, os quais, para fins de tratamento, agrupamos, inicialmente, em categorias relativas a: intelecto, personalidade, emoções, relacionamentos, caráter, aparência e conquistas profissionais; em seguida, classificamos os adjetivos contidos em cada um desses grupos como sendo de conteúdo semântico positivo, negativo ou de ordem mais complexa ${ }^{5}$, tomando como parâmetro os padrões chancelados pelo senso comum. Sendo assim, foi possível chegar em uma espécie de caracterização geral das personagens em questão.

As categorias que ocupam o topo da lista (as cinco mais citadas) resumem $77,6 \%$ dos adjetivos inferidos como sendo adequados para caracterizar as personagens que povoam o romance brasileiro contemporâneo de autoria feminina. Sendo que quase $30 \%$ deles dizem respeito à intelectualidade das personagens a partir de uma visada positiva que as reconhece como sendo inteligentes, cultas e informadas, entre os mais citados. Outros 16,8\% reiteram facetas positivas relacionadas à aparência das personagens, descrevendo-as como sendo atraentes, elegantes, gostosas, vaidosas. As três categorias seguintes somam $31,4 \%$ dos adjetivos arrolados e dizem respeito à personalidade das personagens, seja aqueles de caráter positivo, como boa, responsável, segura e sensata; ou negativo, como arrogante, autoritária e intolerante; ou ainda de ordem mais complexa que transcendem o binarismo do senso-comum, como amalucada, irreverente, desorientada, os quais podem apontar para personagens cujos dilemas precisam ser melhor ponderados dentro dos contextos em que se inserem. Tudo somado, estamos diante de personagens predominantemente inteligentes, bonitas e imersas em questões de ordem subjetiva, já que a caracterização de suas personalidades preponderam sobre as demais categorias, sendo que há aí uma ligeira vantagem dos atributos de conteúdo semântico positivo.

Quanto aos adjetivos de que as próprias escritoras lançaram mão no processo de construção das personagens para descrevê-las fisicamente, há também uma importante preponderância daqueles considerados conformes aos padrões estabelecidos de beleza.

Foram destacados 1306 adjetivos, os quais, para fins de tratamento, agrupamos em três esferas, tomando como parâmetro os padrões estabelecidos de beleza. Assim, chamamos de "conforme" a tais padrões atributos como "firmes" para qualificar os braços da personagem, "impecáveis" para os cabelos ou "escultural” para o corpo; foram entendidos como "contrários" aqueles que evocam, de maneira quase consensual, imagens estéticas que se afastam dos ideais louvacionados da aparência,

5 Consideramos adjetivos "de ordem mais complexa" aqueles que transcendem o binarismo do sensocomum, exigindo reflexões mais acuradas ou circunstanciadas, caso, por exemplo, de "amalucado/a", "problemático/a" ou "oprimido/a". 
como, por exemplo, "vincado" para se referir ao corpo, "amarelos" para os dentes ou "rachados" para os pés; nessa ordem de ideias, indiferentes são aqueles atributos que, simplesmente, qualificam o sujeito sem que estejam implícitos aí juízos préconcebidos de beleza, como entendemos ser as situações em que os olhos, os lábios e os cabelos das personagens são qualificados, respectivamente, como "pretos", "finos" e "marrons".

Sendo assim, cerca de $55 \%$ da adjetivação que constitui fisicamente tanto as personagens femininas, quanto as masculinas as colocam em um patamar de adequação aos padrões vigentes de beleza no contexto sociocultural em que emergem, enquanto apenas um pouco mais de $30 \%$ dos adjetivos em questão concorrem para afastá-las desse ideal. Bem menor ainda (menos de 15\%) é a quantidade de atributos que lhes definem os contornos físicos sem que sejam atualizadas essas referências.

Quanto ao conteúdo semântico dos adjetivos textuais que, em alguma medida, concorrem para a caracterização da personalidade das personagens, observamos que há uma alternância entre os traços de personalidade considerados desejáveis pelo senso comum, como autocentrado/a, bem-humorado/a e pacificador/a, e aqueles que implicam condições problemáticas, como paranoico/a, rancoroso/a e fingido/a - cerca de 50\% para cada grupo de adjetivação. O quadro sugere, mais uma vez, que são as questões de ordem subjetiva e interpessoal aquelas que permeiam com mais intensidade as trajetórias das personagens que povoam o corpus em análise, tanto as femininas, quanto as masculinas.

\section{Das desinterdições: educação \& trabalho}

O objetivo que aqui nos move, qual seja, o de construir um retrato do romance brasileiro contemporâneo de autoria feminina, passa, obviamente, pelo registro do modo como ele representa as diferenças hierarquizadas de gênero, as quais há algumas décadas vem sendo objeto dos debates empreendidos no âmbito dos feminismos. Sendo que, dentre as principais, está a histórica interdição das mulheres à educação, ao mercado de trabalho e à ascensão social daí decorrente. No lugar, o script básico feminino, detalhadamente desenhado ao longo da história das relações sociais pela hegemonia patriarcal, com o objetivo de circunscrever a mulher no espaço "sagrado" do lar. Consequentemente, de promover a naturalização de práticas como a da educação feminina para vida doméstica, a do casamento edificado sobre os alicerces da submissão feminina e da dominação masculina, a da maternidade compulsória, marcada pela dedicação incondicional aos filhos e, por fim, a da aceitação do espaço fechado da casa como sendo o único capaz de lhe propiciar tais realizações.

Como já é bem sabido, tais interdições, todavia, foram aos poucos sendo desestabilizadas em diferentes culturas, de modo que práticas socioculturais consideradas, hoje, óbvias e previsíveis na trajetória da maioria das cidadãs brasileiras, por exemplo, há pouco mais de um século, eram inimagináveis. E, se o acesso aos 
bancos escolares e ao mercado de trabalho, o direito de eleger seus representantes nas instâncias governamentais, o de propriedade e, até mesmo, o de escolher a roupa que se deseja usar ou a pessoa com quem se pretende casar, eram, num passado recente, privilégios exclusivamente masculinos, as mulheres contemporâneas já os tomaram para si. Diversos indicadores levantados pelo Instituto Brasileiro de Geografia e Estatística $(\mathrm{IBGE})^{6}$, com base no último Censo Demográfico de 2010, apontam nessa direção. Esse é o caso da taxa de frequência escolar líquida ajustada, indicador que mede a proporção de pessoas que frequentam a escola no nível de ensino adequado à sua faixa etária, ou já concluíram esse nível, tendo como parâmetro o número total de pessoas da mesma faixa etária. Na faixa dos 15 a 17 anos (ensino médio), o percentual da frequência das mulheres na escola é cerca de 10\% maior que a masculina. Essa diferença, todavia, é ainda maior no nível "superior completo", especialmente na faixa dos 25 a 44 anos: o indicador de mulheres que completaram a graduação aí é de $37,9 \%$ superior ao dos homens.

Quanto à inserção das mulheres no mercado de trabalho, as últimas décadas têm registrado também importantes avanços. Entre os anos 2000 e 2010, por exemplo, a taxa de atividade masculina caiu de $79,7 \%$ para $75,7 \%$, enquanto a feminina aumentou 50,1\% para 54,6\%, embora as mulheres permaneçam recebendo (é bom que se registre) apenas $3 / 4$ dos valores recebidos pelos homens na mesma função.

Tendo isso vista, o que se espera é que a literatura, movida que é pelo espírito da época, do mesmo modo como faz reverberar nele as situações que problematiza e representa, atualize-o nas suas páginas, por meio de temas, de registro de situações e/ou de trajetórias de personagens que, de algum modo, ecoem esse estado de coisas.

As trajetórias das personagensquepovoam o romancebrasileiro contemporâneo de autoria feminina fazem propagar, em alguma medida, essas mudanças no universo representado. Como dissemos anteriormente, das 618 personagens analisadas, 350 ou $56,6 \%$ são femininas e, dentre as que protagonizam as histórias, 138 ou $66,4 \%$ são mulheres. Trata-se de uma condição que poderíamos tomar, talvez, como o ponto de partida de uma série de subversões feministas que o conjunto de romances em questão vai operando, relacionadas ao modo de estar dos sujeitos na sociedade sob a perspectiva das relações de gênero.

No que diz respeito ao grau de escolaridade das personagens, perto de 40\% delas são construídas de modo a deixar explicitado em suas trajetórias que possuem curso superior, sendo que algumas têm também formação em nível de pósgraduação. Desse total, cerca da metade são femininas. Se isolarmos, todavia, os/as protagonistas, o número daqueles/as representados/as com esse nível de escolaridade sobe para 43,3\% (90), sendo que as protagonistas sozinhas são responsáveis por $70 \%$ (63) dessas ocorrências. Isso implica dizer que dentre as 138 protagonistas, 63 possuem nível superior, de modo que 5 dentre elas possuem também pós-graduação; enquanto dentre os 69 protagonistas, 22 são representados com nível superior, sendo que, igualmente, 5 dentre eles são pós-graduados.

6 Consultar https://biblioteca.ibge.gov.br/visualizacao/livros/liv1o1551_informativo.pdf 
Tudo ponderado, as personagens femininas que protagonizam as narrativas em questão são mais escolarizadas que as masculinas, mesmo considerando-as proporcionalmente, já que as primeiras estão em maior número: $45,7 \%$ contra 39,3\%, no que diz respeito ao nível superior e de pós-graduação. Nos demais níveis, embora os números sejam menos expressivos, os percentuais femininos permanecem mais elevados, com exceção de dois casos de protagonistas analfabetas.

No que diz respeito à representação de mulheres inseridas no mercado de trabalho, e ainda tendo na mira o recorte privilegiado dos/as protagonistas, a constatação da pesquisa é a de que o índice das presenças, em certa medida, é compatível com os níveis de escolaridade femininos acima referidos. Embora dentre os temas e abordagens mais recorrentes nesse corpus literário, não estejam aqueles que gravitam no entorno do trabalho e das relações profissionais, quase $60 \%$ dos/ as protagonistas representados/as exercem algum tipo de trabalho remunerado no presente da narrativa, sendo que entre as mulheres tal condição atinge 55,8\%.

Os índices de inserção das protagonistas no mercado de trabalho é cerca de $10 \%$ menor em relação aos protagonistas masculinos, um quadro, portanto, mais favorável do que o registrado pelo IBGE em relação a homens e mulheres na realidade extraliterária. Essa diferença, todavia, sobe para um pouco mais de $20 \%$ quando analisamos esses dados a partir do conjunto total das personagens. Entre as personagens masculinas, mais de $70 \%$ estão inseridas, de alguma maneira, no mercado de trabalho; enquanto, entre as femininas, o percentual cai para cerca de $47 \%$. Trata-se de uma discrepância que, embora pareça descabida, espelha a realidade brasileira registrada pelo IBGE no censo de 2010, qual seja, a de que apenas 54,6\% das mulheres estão inseridas no mercado de trabalho. Se comparado aos percentuais obtidos nos censos das décadas anteriores, esses números apontam na direção de importantes avanços nos movimentos de deslocamento feminino da esfera privada para a pública, promovidas pelos feminismos.

Segundo o que destaca Dalcastagnè (2005), a propósito dos números obtidos no mapeamento já referido acerca da personagem no romance brasileiro contemporâneo, mesmo estando as mulheres hoje muito mais inseridas na esfera pública do que há algumas décadas, o romance brasileiro registra mal tais mudanças, "continuando a privilegiar a associação entre a figura feminina, o lar e a família” (p. 27). Tendo isso em vista, somos levadas a concluir aqui que, na contramão dessa tendência, o romance brasileiro contemporâneo de autoria feminina, ao se desdobrar majoritariamente no entorno de trajetórias e identidades femininas, registra, de maneira bastante expressiva, os avanços conquistados pelas mulheres no contexto sociocultural em que emergem.

Outro dado que avança nessa direção diz respeito à caracterização das ocupações das personagens face aos papéis tradicionais de gênero. Se as personagens femininas, sobretudo as protagonistas, estão razoavelmente inseridas no mercado de trabalho, conforme demonstram os dados acima, o que podem revelar as funções que as mesmas desempenham? A tabela que segue trata dessa questão: 
Tabela 1. Profissão atual e tradição de gênero

\begin{tabular}{|l|c|c|c|c|}
\hline & $\begin{array}{c}\text { Amostra total } \\
\text { de personagens } \\
\text { femininas }\end{array}$ & $\begin{array}{c}\text { Amostra total } \\
\text { de personagens } \\
\text { masculinas }\end{array}$ & $\begin{array}{c}\text { Protagonista } \\
\text { feminina }\end{array}$ & $\begin{array}{c}\text { Protagonista } \\
\text { masculino }\end{array}$ \\
\hline $\begin{array}{l}\text { ocupação tradicional } \\
\text { feminina }\end{array}$ & $29,6 \%(104)$ & $5,6 \%(15)$ & $28,3 \%(39)$ & $4,4 \%(3)$ \\
\hline $\begin{array}{l}\text { ocupação tradicional } \\
\text { masculina }\end{array}$ & $19,7 \%(69)$ & $55,3 \%(147)$ & $24,6 \%(34)$ & $43,5 \%(30)$ \\
\hline $\begin{array}{l}\text { ocupação sem } \\
\text { restrição de gênero }\end{array}$ & $17,7 \%(62)$ & $21,1 \%(56)$ & $19,6 \%(27)$ & $33,3 \%(23)$ \\
\hline $\begin{array}{l}\text { sem indícios/não se } \\
\text { aplica }\end{array}$ & $33,1 \%(116)$ & $18,1 \%(48)$ & $27,5 \%(38)$ & $18,8 \%(13)$ \\
\hline TOTAL & $100 \%(350)$ & $100 \%(266)$ & $100 \%(138)$ & $100 \%(69)$ \\
\hline
\end{tabular}

Os valores da tabela são os percentuais em coluna estabelecidos sobre 618 observações/amostra total (colunas 1 e 2) e sobre 208 observações, definidas pelo filtro da população 'protagonistas' (colunas 3 e 4).

Fonte: pesquisa "Literatura de autoria feminina brasileira contemporânea: escolhas inclusivas?"

As "ocupações tradicionais femininas" são aqui entendidas como aquelas que, segundo a ética patriarcal, eram consideradas adequadas à mulher ou "naturalmente" de "vocação" feminina, até que as intervenções feministas, no decorrer do século XX, pudessem modificar esse modo de pensar, caso das professoras, governantas, enfermeiras, cuidadoras, etc. Do mesmo modo que as "ocupações tradicionais masculinas" são aquelas que eram consideradas adequadas ao sexo masculino, segundo os mesmos parâmetros patriarcais, como a dos médicos, advogados, engenheiros, etc. Nessa ordem de ideias, as "ocupações sem restrição de gênero" são aquelas por onde homens e mulheres, na primeira metade do século XX, transitavam sem maiores problemas, caso dos/as comerciários/as, funcionários/as de empresas; costureiros/as; artistas; vendedores/as, etc.).

Tendo isso em vista e considerando que dentre as principais demandas dos feminismos contemporâneos estão a igualdade salarial para a mesma função desempenhada por homens e mulheres e a desinterdição à mulher de redutos masculinos no interior de profissões como as engenharias, a medicina e o direito, o que salta aos olhos nessa tabela é o fato de as personagens femininas, tomadas em conjunto e, também, a partir do filtro "protagonistas", transitarem pelas áreas de atuação tipicamente masculinas ou sem restrição de gênero. No caso das protagonistas, por exemplo, esses percentuais chegam a $24,6 \%$ e a 19,6\%, respectivamente. Ao somarmos esses percentuais, contabilizamos $44,2 \%$, um número consideravelmente superior aos $28,3 \%$ referentes àquelas que permanecem insuladas no gueto das clássicas e desvalorizadas atividades consideradas femininas por excelência. 
Já em relação a protagonistas masculinos, as escritoras seguem representando-os nos lugares em que sempre estiveram, ou seja, nas ocupações tradicionalmente desempenhadas pelos homens (45,3\%) ou naquelas consideradas sem restrição de gênero (33,3\%). Percentuais esses que, se somados, atingem vultuosos 78,6\%. Trata-se, é certo, de um espelho da sociedade, assim como os demais dados levantados cujos destaques reunimos na tabela 2 abaixo, construída a partir do conjunto total das personagens:

Tabela 2. Sexo da personagem \& trabalho

\begin{tabular}{|c|c|c|c|c|}
\hline & $\begin{array}{c}\text { Trabalho bem ou } \\
\text { moderadamente } \\
\text { remunerado }\end{array}$ & $\begin{array}{c}\text { Trabalho } \\
\text { remunerado e } \\
\text { posição de chefia }\end{array}$ & $\begin{array}{c}\text { Serviço } \\
\text { doméstico não } \\
\text { remunerado }\end{array}$ & $\begin{array}{c}\text { Dependência } \\
\text { financeira do } \\
\text { parceiro }\end{array}$ \\
\hline masculino & $57,1 \%(104)$ & $65,3 \%(64)$ & $20,5 \%(24)$ & $14,3 \%(10)$ \\
\hline feminino & $42,9 \%(78)$ & $34,7 \%(34)$ & $79,5 \%(93)$ & $85,7 \%(60)$ \\
\hline Total & $\mathbf{1 0 0} \%(\mathbf{1 8 2})$ & $\mathbf{1 0 0} \%(\mathbf{7 4})$ & $\mathbf{1 0 0} \%(\mathbf{1 1 7})$ & $\mathbf{1 0 0} \%(\mathbf{7 0})$ \\
\hline
\end{tabular}

Os valores da tabela são os percentuais em coluna estabelecidos sobre 618 observações.

Fonte: pesquisa "Literatura de autoria feminina brasileira contemporânea: escolhas inclusivas?"

O que se constata por meio desse painel é que o universo ficcional das escritoras brasileiras contemporâneas não só registra os avanços empreendidos pelas mulheres do tempo nas esferas educacional e profissional, mas também as mazelas reminiscentes das diferenças hierarquizadas de gênero referentes a essa última. As personagens femininas representadas no grupo daqueles/as cujo trabalho é bem ou moderadamente remunerado estão em número 14,2\% menor. As diferenças, todavia, são mais gritantes em relação às hierarquias dos cargos que ocupam: dentre as personagens que ocupam postos de chefia, mais de $65 \%$ são masculinas. E, dentre as que fazem serviço doméstico não remunerado, quase $80 \%$ são femininas, como também é feminina a maioria absoluta das personagens representadas como sendo dependentes financeiramente dos parceiros - 85,7\%. São para sanar diferenças como essas, infelizmente ainda muito presentes no mundo contemporâneo, que os feminismos vêm se articulando.

Sendo assim, talvez pudéssemos especular que o imaginário das escritoras brasileiras contemporâneas, projetado nessa amostra, parece elaborar um quadro em que diversas realidades relacionadas ao modo de estar da mulher na sociedade são recrutadas (a histórica segregação/opressão feminina, as intervenções feministas e as conquistas já computadas) e, ao mesmo tempo, transgredidas e/ ou depuradas de acordo com a subjetividade e, obviamente, a perspectiva social das mesmas. 


\section{Dos espaços conquistados: qual o lugar da mulher no romance contemporâneo de mulheres?}

Em A casa e a rua, Roberto DaMata reflete sobre a sociedade brasileira como um sistema de normas próprias que se materializam e se atualizam através dos indivíduos e das categorias sociológicas casa e rua, tomadas enquanto domínios culturais institucionalizados que despertam ações, reações, leis, emoções, etc.

Ao mesmo tempo em que remetem, respectivamente, ao espaço privado da proteção e do aconchego familiar (bom/belo/moral) e ao espaço público das batalhas cotidianas (ruim/feio/confuso/desordeiro), ambas as categorias podem aparecer revestidas de múltiplas simbologias. De modo especial, a conjunção sujeito feminino e espaço remete a conotações bastante complexas que em muito transcendem a aparente simplicidade da polaridade casa X rua.

A pergunta que move a indagação que fizemos no título desse subitem acerca do lugar que a mulher ocupa, nesse primeiro quartel do século XXI, nas representações empreendidas pelo romance de autoria feminina, passa pelo paradoxal desconforto $\mathrm{X}$ alento, muitas vezes, experimentado quando de nossas análises da literatura de mulheres publicada nas últimas décadas do século XX. Se de um lado, tais narrativas fazem emergir imagens de mulheres confinadas em espaços de opressão, se debatendo contra os mecanismos de cerceamento feminino vislumbrados por entre práticas sociais corriqueiras, por outro, ganha relevo o fato de tal estado de coisas estar sendo problematizado no universo literário, a partir da perspectiva feminina, historicamente tornada inócua. A escritora brasileira da segunda metade do século passado foi enfática, pode-se dizer, ao promover o desnudamento dos desmandos do patriarcado. Analisado a partir da perspectiva do feminismo crítico, o quadro comportava, grosso modo, dois grandes filões literários: a literatura canônica e/ou a contemporânea de maior circulação no país, reduplicando, via representação, ideologias tradicionais, como a patriarcal, entre outras; e a literatura de autoria feminina, imbuída da missão de protestar contra tais ideologias, sobretudo, contra aquelas calcadas na dominação de um gênero sobre o outro.

A obra de Clarice Lispector abre alas para a tradição brasileira de escritoras feministas. Os ontológicos contos de Laços de família, por exemplo, flagram personagens femininas em momentos de lucidez ou crise em relação ao lugar que ocupam na sociedade, firmando-se como um convite à reflexão e à contestação de paradigmas estabelecidos; em sua esteira, aparecem as obras de Lygia Fagundes Telles, de Nélida Piñon, de Lya Luft, de Helena Parente Cunha, entre tantas outras, de cujas páginas emergem, igualmente, figuras femininas inquietas, angustiadas, e conscientes de que se encontram fora de lugar. O espaço que lhes fora reservado na sociedade, em função de seu sexo, não lhes representa.

Em Espaço e literatura: introdução à topoanálise (2007), Ozires Borges Filho,

define a topoanálise como sendo a investigação do espaço representado na obra 
literária, a partir de sua riqueza e dinamicidade, enfatizando seus efeitos de sentido psicológicos ou objetivos, sociais ou íntimos - suscitados para além da denotação de sua materialidade física. Nesse sentido, uma abordagem temática do espaço, definida como sendo aquela em que "estudam-se os valores simbólicos, imaginários que impregnam a representação do espaço no texto literário” (p. 4), constitui-se como uma aliada na tarefa de equacionar o lugar sociocultural que a mulher ocupa na ficção contemporânea de autoria feminina.

Tendo em vista a dicotomia casa X rua - tomada, nas ponderações de DaMata (200o), como espaço emblemático de segurança, de um lado, e de risco, de outro, razão pela qual o primeiro, no imaginário patriarcal, mostra-se mais adequado à mulher e o segundo ao homem - perscrutamos em que medida as personagens da amostra (masculinas e femininas) andam na rua. Os resultados a que chegamos revelam que a quantidade de personagens femininas quase equivalente ao número de personagens masculinas que no transcorrer de suas trajetórias são flagradas andando/flanando pelas ruas da cidade. Algumas andam mais outras andam menos. No entanto, ao somarmos os percentuais das que andam muito aos daquelas/es que andam menos, mas andam nas ruas da cidade, chegamos a $71,8 \%$ e $71,4 \%$, respectivamente. Ao isolarmos os/as protagonistas, os números são muito parecidos: $78,3 \%$, no caso das mulheres, e $79,7 \%$, no dos homens. Embora pareça uma constatação banal para os padrões contemporâneos, tratase da representação/construção de uma realidade feminina bastante diferente daquela fixada nas representações/construções tradicionais, em que imagens de mulher aparecem sempre associadas ao ambiente fechado da casa, às voltas com os afazeres domésticos, com a educação dos/as filhos/as e o cuidado com o marido, afastadas do "perigo de viver", como bem assinala Clarice Lispector no conto "Amor", de Laços de família; ou então, vivendo a angústia do confinamento, mesmo sem se dar conta dele.

$\mathrm{O}$ fato de essas personagens se deslocarem por entre a insegurança e a desconfiança das ruas, longe da "proteção da casa", nos termos de DaMata (200o), pode implicar, na esfera simbólica das espacialidades, o descolamento de estereótipos sexistas, frequentemente relacionados a situações arbitrárias de confinamento e/ou de cerceamentos diversos, implícitos na ideia de casa, enquanto espaço institucionalizado que pressupõe distinções de gênero e de idade, matizadas por configurações de poder. A recorrência, portanto, de imagens femininas em situação de deslocamento cria efeitos de sentido que apontam, de chofre, para uma ruptura na seara das representações, mesmo antes de procedimentos analíticos individualizados das personagens em questão. Trata-se de um nicho de especulação que sinaliza a tendência de a literatura de autoria feminina contemporânea fixar em meio aos enredos que engendra imagens de mulher associadas ao enfrentamento dos riscos que a rua oferece; ou, de outro lado, à negação do desejo de deverem/quererem ser "poupadas" dos perigos de viver; ou ainda simplesmente à agência, entendida como o avesso da estagnação/ resignação. 
A constatação de que as personagens de ambos os sexos andam/ocupam nas/ as ruas da cidade, cumprido as rotas que lhes são creditadas na escrita de mulheres contemporâneas, sugere que o escrutínio dos lugares para onde se dirigem consiste em um importante sinalizador do lugar das mulheres nesses romances. Na tabela que segue, destacamos, dentre os espaços frequentados pelos/as protagonistas, os dez mais recorrentes:

Tabela 3. Locais frequentados pelas personagens

\begin{tabular}{|l|c|c|c|}
\hline & feminino & masculino & TOTAL \\
\hline estabelecimentos gastronômicos & $12,2 \%(61)$ & $12,9 \%(31)$ & $12,5 \%(93)$ \\
\hline residência de outros/as & $10,2 \%(51)$ & $9,6 \%(23)$ & $10,1 \%(75)$ \\
\hline lazer em espaços públicos & $10,6 \%(53)$ & $8,3 \%(20)$ & $9,9 \%(74)$ \\
\hline estabelecimentos médicos & $8,2 \%(41)$ & $7,1 \%(17)$ & $7,8 \%(58)$ \\
\hline lazer em espaço restrito & $7,2 \%(36)$ & $7,9 \%(19)$ & $7,5 \%(56)$ \\
\hline hotelaria & $6,4 \%(32)$ & $7,1 \%(17)$ & $6,7 \%(50)$ \\
\hline supermercado/(pequeno) comércio & $6,2 \%(31)$ & $4,6 \%(11)$ & $5,6 \%(42)$ \\
\hline estabelecimentos educacionais & $6,0 \%(30)$ & $4,6 \%(11)$ & $5,5 \%(41)$ \\
\hline estabelecimentos de trânsito & $4,2 \%(21)$ & $3,8 \%(9)$ & $4,2 \%(31)$ \\
\hline estabelecimentos religiosos & $4,6 \%(23)$ & $2,5 \%(6)$ & $3,9 \%(29)$ \\
\hline$(\ldots)$ & $(\ldots)$ & $(\ldots)$ & $(\ldots)$ \\
\hline Total & $100 \%(500)$ & $100 \%(240)$ & $100 \%(740)$ \\
\hline
\end{tabular}

Os valores da tabela são os percentuais em coluna estabelecidos sobre 740 citações.

Esta tabela é construída sobre o estrato / filtro da população 'protagonistas'

Fonte: pesquisa "Literatura de autoria feminina brasileira contemporânea: escolhas inclusivas?"

Há que se considerar, antes de mais nada, que o fato de serem esses, e não outros, os lugares mais frequentados pelos/as protagonistas está intimamente relacionado às temáticas predominantes nesse conjunto de romances, quais sejam, questões familiares, relações amorosas, deslocamentos espaciais e identitários. Isso posto, claro nos parece que os/as protagonistas, independentemente do sexo, transitam, em percentuais muito próximos entre si (com diferenças de cerca o,5\%), por lugares de convívio social, como restaurantes e afins, residências de amigos e parentes, espaços privados de lazer, como clubes, cinemas e museus; também frequentam, em igual medida, espaços considerados de trânsito como hotéis, estações rodoferroviárias e aeroportos, 
portanto, viajam com a mesma frequência; as protagonistas, todavia, aparecem mais frequentemente em espaços ligados aos cuidados com a saúde $(+1,1 \%)$, ao comércio $(+1,6 \%)$, à educação $(+1,4 \%)$, à religião $(+2,1 \%)$ e ao lazer em espaços públicos, como praças, parques, praias $(+2,3 \%)$. No limite, o quadro comporta um retrato dos espaços urbanos, onde transcorrem mais de $80 \%$ dos enredos, no qual perfis femininos aparecem por toda parte, às vezes em meio aos masculinos, às vezes um passo à frente em relação a eles, ocupando lugares que, embora lhes sejam "devidos", sempre lhes foram interditados, tanto no universo ficcional, quando na realidade empírica.

De outra perspectiva, tanto quanto o fato de as personagens ocuparem as ruas da cidade e os seus nichos de convivência e/ou de serviços, também nos parece sintomático do lugar que a escritora brasileira contemporânea entende ser o das personagens, pensadas em seu gênero, os espaços que mais lhes servem de cenários às suas ações no âmbito da casa. Tanto quanto a dicotomia casa X rua, os pares binários cozinha/área de serviço X sala, cozinha/área de serviço $\mathrm{X}$ escritório/sala de estudos, dependências de empregados/as X quartos e sala, podem nos oferecer pistas acerca do lugar simbólico que tais personagens ocupam nesses romances. Como na situação anterior, os dados levantados apontam para uma significativa mudança em relação aos padrões de pensamento patriarcais, segundo os quais as mulheres são, frequentemente, associadas aos ambientes da casa considerados menos nobres, tomados como o seu "devido lugar", na hierarquia de gênero aí pressuposta, até o advento dos primeiros frutos do feminismo. A cozinha e a área de serviço são frequentadas apenas 5\% mais pelas personagens femininas que pelas masculinas, se isolarmos os/as protagonistas, essa diferença cai para exatos $1 \%$; os percentuais que contabilizam a frequência das personagens de ambos os sexos à sala de estar, espaço que simbolicamente remete à vida social, são praticamente iguais, sendo que, novamente, o número de protagonistas do sexo feminino presentes é pouco mais de $1 \%$ maior em relação aos do masculino; as personagens femininas se fazem presentes também, embora em número sensivelmente menor (- 3,5\%), no escritório/sala de estudos, lugar de trabalho intelectual, tradicionalmente ligado à imagem masculina; e, quanto às personagens que sequer aparecem no espaço doméstico, os percentuais verificados na trajetória das masculinas não são maiores que $6 \%$ em relação às femininas.

Sendo assim, e talvez movidas pelo otimismo subjacente à ideia que impulsionou essa pesquisa, já podemos afirmar que o lugar das mulheres no romance contemporâneo de mulheres são todos os lugares, ou são os lugares que melhor se alinham às abordagens e conflitos experienciados no interior das histórias aí narradas. 


\section{Das subversões corporais: sexualidade \& maternidade}

Os debates acerca da sexualidade feminina, como é bem sabido, estiveram, nos anos 1970, no centro da quarta onda do feminismo brasileiro ${ }^{7}$, ao lado daqueles que se insurgiam contra a ditadura militar e a censura que marcavam aquele triste momento da história do Brasil, momento de culto e de padronização das masculinidades, segundo a fixidez dos valores patriarcais e militares. As ideias de base dos discursos que circunscreviam social e culturalmente o corpo feminino como objeto desfrutável à disposição dos sujeitos masculinos foram definitivamente enfraquecidas. Na avaliação de Duarte (2003), trata-se da onda mais exuberante, aquela que vai alterar radicalmente os costumes e tornar as reivindicações anteriores senso comum, garantindo às gerações seguintes a capacidade de legitimar a igualdade de direitos entre os sexos e de fazer escolhas, independentemente do sexo com que se viesse a nascer. À mulher, portanto, a maternidade deixa de ser uma imposição para se tornar uma opção: "a tecnologia anticoncepcional torna-se a grande aliada do feminismo ao permitir à mulher igualar-se ao homem no que toca à desvinculação entre sexo e maternidade, sexo e amor, sexo e compromisso" (Duarte, 2003, p. 13).

Na literatura de autoria feminina brasileira contemporânea, essas conquistas feministas, propagadas no tempo, constituem-se nos alicerces sobre os quais as personagens são construídas. As mulheres escritoras parecem se imbuir da missão de representar e problematizar a sexualidade do gênero feminino, numa espécie de resposta às práticas misóginas por meio das quais as abordagens do tema vinham historicamente sendo (mal) representadas na literatura hegemônica.

A orientação sexual das personagens, todavia - como já era de se esperar tendo em vista a ordem das coisas no contexto em que se inserem as escritoras e os romances em foco-, obedece aos esquemas tradicionais de sexo-gênero-desejo. Ao sinalizar que mais de $85 \%$ das personagens analisadas são heterossexuais, esses dados reverberam, no limite, a normatividade sexual reinante no contexto que lhes dá origem. Parece que, muito provavelmente, estamos diante da representação da heterossexualidade compulsória de que fala Butler no seu Problemas de gênero (2003). Segundo a filósofa, a coerência entre sexo, gênero e sexualidade é construída culturalmente. A matriz cultural que institui a identidade de gênero do sujeito (sua percepção sobre o próprio gênero) exige que certos tipos de identidade não possam existir: aquelas em que o gênero não decorre do sexo e aquelas em que a orientação sexual (gênero pelo qual o sujeito se sente atraído física e emocionalmente) não decorre nem do sexo nem do gênero. Daí falar que, no nosso meio e, muito provavelmente, para além dele, a heterossexualidade é compulsória, embora não seja óbvia. No conjunto dos

7 De acordo com Duarte (2003), a primeira onda feminista ocorreu em torno de 1830 e se alicerçou sobre reivindicações do direito básico de a mulher poder aprender a ler e a escrever; a segunda surgiu por volta de 1870 e foi marcada pela publicação de muitos jornais e revistas de cunho feminista, iniciou a luta pela cidadania feminina, levantando a bandeira do direito da mulher ao voto, além da igualdade de direitos à educação e ao trabalho profissional; a terceira, surgida nos primeiras décadas do século XX, consistiu em um movimento bem mais organizado de mulheres clamando alto pelo direito ao voto, à propriedade, ao curso superior e à ampliação do campo de trabalho. 
romances analisados, não é diferente, avulta a pretensa "normalidade" da realidade extraliterária e as personagens são construídas "naturalmente" como heterossexuais.

Sendo assim, a pequena variação em relação à essa normatividade poderia ser tomada como práticas subversivas por parte de algumas escritoras que ousaram colocar em cena 22 personagens femininas (6,2\%) e 13 masculinas (4,8\%) cuja orientação sexual extrapola os limites da normatividade dominante.

Além disso, 28 personagens femininas e 22 masculinas, por volta de $8 \%$ em ambos os casos, são construídas de modo que as escolhas das escritoras implícitas nesse processo não contemplam a orientação sexual, ou por serem crianças ou por estarem envolvidas em dilemas que passam ao largo dessa questão. Seja como for, cerca de $15 \%$ das personagens do corpus em questão se esquivam, de algum modo, da heterossexualidade compulsória, abrindo brechas nos padrões binários de inteligibilidade de gênero, para que outros corpos performáticos, como nos ensina Butler (2003), possam encenar seu gênero e sexualidade fora das estruturas da dominação masculina e do padrão normativo.

As duas próximas tabelas demonstram, respectivamente, a frequência da atividade sexual das personagens e o modo como se sentem em relação ao sexo, descortinando nossa percepção da literatura de autoria feminina brasileira contemporânea como um discurso que segue promovendo deslocamentos em relação ao que é próprio ou impróprio às mulheres:

Tabela 4. Vida sexual da personagem

\begin{tabular}{|l|c|c|c|c|}
\hline & feminino & masculino & ambíguo & TOTAL \\
\hline sem indícios/não se aplica & $56,9 \%(199)$ & $55,6 \%(148)$ & $0,0 \%(0)$ & $56,2 \%(347)$ \\
\hline realidade frequente & $21,9 \%(77)$ & $21,4 \%(57)$ & $0,0 \%(0)$ & $21,7 \%(134)$ \\
\hline realidade eventual & $14,5 \%(51)$ & $15,4 \%(41)$ & $50,0 \%(1)$ & $15,0 \%(93)$ \\
\hline realidade muito frequente & $6,0 \%(21)$ & $6,8 \%(18)$ & $50,0 \%(1)$ & $6,5 \%(40)$ \\
\hline imaginária & $0,3 \%(1)$ & $0,8 \%(2)$ & $0,0 \%(0)$ & $0,5 \%(3)$ \\
\hline virtual & $0,3 \%(1)$ & $0,0 \%(0)$ & $0,0 \%(0)$ & $0,2 \%(1)$ \\
\hline TOTAL & $100 \%(350)$ & $100 \%(266)$ & $100 \%(2)$ & $100 \%(618)$ \\
\hline
\end{tabular}

Os valores da tabela são os percentuais em coluna estabelecidos são os percentuais em coluna estabelecidos sobre 618 observações.

Fonte: pesquisa "Literatura de autoria feminina brasileira contemporânea: escolhas inclusivas?"

Esses números evocam a ideia de que, nesse recorte literário, personagens masculinas e femininas são representadas vivenciando sua sexualidade de tal maneira a colocar em xeque o duplo padrão de comportamento historicamente esperado para homens e mulheres ao longo do tempo, e incentivado pela sociedade masculinista 
burguesa: de um lado, o macho inveterado, de virilidade intocada, marcado pelo querer e pelo poder; de outro, a fêmea objetificada, o ser-para-o-outro ou o ser-parao-homem, nos termos de Touraine (2007), destituído de subjetividade e de desejo, tendo o dever como único horizonte.

Se as trajetórias de quase $60 \%$ das personagens de ambos os sexos não trazem indícios da frequência com que fazem sexo, dadas as especificidades das tramas em que se encontram envolvidas, mais de $21 \%$ delas deixam registrado aí que fazem sexo com frequência, outros $6 \%$ ou mais o fazem com muita frequência. Na abordagem que aqui nos interessa, trata-se de registrar nessas páginas literárias a equivalência do direito à sexualidade entre os gêneros, antes privilégio apenas dos sujeitos masculinos. As informações contidas na tabela a seguir vêm complementar essa ideia:

Tabela 5. Como a personagem percebe o sexo?

\begin{tabular}{|l|c|c|c|c|}
\hline & feminino & masculino & ambíguo & TOTAL \\
\hline sem indícios/não se aplica & $62,6 \%(219)$ & $65,4 \%(174)$ & $50,0 \%(1)$ & $63,8 \%(394)$ \\
\hline gosta & $32,2 \%(113)$ & $32,0 \%(85)$ & $50,0 \%(1)$ & $32,2 \%(199)$ \\
\hline aceita & $6,0 \%(21)$ & $1,5 \%(4)$ & $0,0 \%(0)$ & $4,0 \%(25)$ \\
\hline evita & $1,4 \%(5)$ & $1,9 \%(5)$ & $0,0 \%(0)$ & $1,6 \%(10)$ \\
\hline TOTAL & $100 \%(358)$ & $100 \%(268)$ & $100 \%(2)$ & $100 \%(628)$ \\
\hline
\end{tabular}

Os valores da tabela são os percentuais em coluna estabelecidos são os percentuais em coluna estabelecidos sobre 618 observações.

Fonte: pesquisa "Literatura de autoria feminina brasileira contemporânea: escolhas inclusivas?"

Mais de $32 \%$ das personagens femininas e, curiosamente, iguais $32 \%$ das masculinas gostam de sexo, são poucas as que apenas o aceitam $(4,5 \%$ a mais entre as mulheres) ou o evitam. Isso implica dizer que, para as personagens femininas representadas nesse corpus literário, sexo não é sinônimo de obrigação ou de dever conjugal. Tampouco está atrelado à maternidade, já que mais de 30\% delas não têm filhos.

Isso, todavia, não causa espanto já que a produção literária de autoria feminina, como bem avalia Schmidt (2012), desde o final do século XIX vem, sistemática e insistentemente, representando novas configurações das relações entre "mulher, corpo e natureza, (...) na perspectiva de deslocamentos e resistências à construção do corpo como lugar da reprodução da feminilidade, o que significa rasurar o princípio da mulher 'natural' e questionar a metanarrativa patriarcal da subordinação" (p. 12). As pioneiras dessa tradição, segundo a pesquisadora, exploraram com tanta pertinência a relação entre identidade, subjetividade, corpo e natureza que podem ser consideradas as precursoras das teorias feministas que viriam a se desenvolver no 
final do século XX, as quais são agora replicadas nos romances recentes de mulheres. A sexualidade feminina não só não é retratada aí como tabu, mas, muitas vezes, consiste na sua temática central, cujo desenvolvimento parece estar a serviço da produção de novos sentidos para os corpos femininos, tradicionalmente tomados como dóceis e disciplinados, imbuídos da missão da reprodução como fim maior, conforme reza a oposição conceitual masculino/feminino fundamentada no par cultura/natureza.

Também os dados contidos na próxima tabela sugerem representações de experiências de corporalidades femininas e masculinas que, no conjunto, desessencializam os pares binários acima referidos.

Tabela 6. Número de parceiros/as sexuais da personagem

\begin{tabular}{|l|c|c|c|c|}
\hline & feminino & masculino & ambíguo & TOTAL \\
\hline um & $47,7 \%(167)$ & $47,0 \%(125)$ & $50,0 \%(1)$ & $47,4 \%(294)$ \\
\hline sem indícios/não se aplica & $24,8 \%(87)$ & $22,9 \%(61)$ & $0,0 \%(0)$ & $23,9 \%(148)$ \\
\hline dois & $15,4 \%(54)$ & $17,7 \%(47)$ & $0,0 \%(0)$ & $16,3 \%(101)$ \\
\hline entre quatro e dez & $6,3 \%(22)$ & $3,0 \%(8)$ & $0,0 \%(0)$ & $4,9 \%(30)$ \\
\hline três & $2,6 \%(9)$ & $6,0 \%(16)$ & $0,0 \%(0)$ & $4,0 \%(25)$ \\
\hline mais de dez & $3,1 \%(11)$ & $3,4 \%(9)$ & $50,0 \%(1)$ & $3,4 \%(21)$ \\
\hline TOTAL & $100 \%(350)$ & $100 \%(266)$ & $100 \%(2)$ & $100 \%(618)$ \\
\hline
\end{tabular}

Os valores da tabela são os percentuais em coluna estabelecidos são os percentuais em coluna estabelecidos sobre 618 observações.

Fonte: pesquisa "Literatura de autoria feminina brasileira contemporânea: escolhas inclusivas?"

No âmbito do feminismo crítico, é consenso já há bastante tempo o fato de as obras literárias canônicas representarem mulheres a partir de repetições de estereótipos calcados nos binarismos que alicerçam os padrões de comportamento sancionados pela cultura patriarcal. De um lado, proliferam imagens de mulheres sedutoras, perigosas e imorais, as quais, habitualmente, acabam punidas e/ou rejeitadas pelo senso comum daqueles que as cercam; de outro, as mulheres ingênuas, indefesas e/ou incapazes a necessitarem do amparo masculino, ou mesmo as mulheres-anjo, sempre prontas a se sacrificarem pelos outros e, por isso, agraciadas, na tessitura do texto, com uma conotação positiva.

Se fossem esses os parâmetros atuais, alguns dos valores da tabela acima, por si sós, colocariam um número bastante expressivo de personagens femininas no eixo negativo a que nos referimos, já que cerca de 30\% delas, a mesma proporção das masculinas, diga-se, têm dois ou mais parceiros sexuais ao longo de suas trajetórias. 
Considerando o contexto geocultural em que emergem, não somos, absolutamente, autorizadas a classificá-las, a partir desse dado, como imorais ou algo que o valha. Certamente que estamos diante da representação do novo normal no que diz respeito à sexualidade feminina na realidade extraliterária em tempos feministas.

Esse novo estado de coisas é corroborado mediante os dados destacados abaixo que reúnem as informações obtidas quando, na pesquisa em questão, indagamos: com quem a personagem faz sexo?

Tabela 7. com quem a personagem faz sexo?

\begin{tabular}{|c|c|c|c|}
\hline Parceiro/a sexual & feminino & masculino & TOTAL \\
\hline cônjuge (casamento civil) & $28,0 \%(130)$ & $30,2 \%(110)$ & $29,0 \%(240)$ \\
\hline sem indícios/não se aplica & $22,2 \%(103)$ & $19,0 \%(69)$ & $20,8 \%(172)$ \\
\hline namorado/a ou união estável & $18,4 \%(85)$ & $18,9 \%(69)$ & $18,6 \%(154)$ \\
\hline amante & $10,8 \%(50)$ & $12,4 \%(45)$ & $11,5 \%(95)$ \\
\hline parceiro/a eventual & $8,2 \%(38)$ & $8,8 \%(32)$ & $8,5 \%(70)$ \\
\hline amigo/a, vizinho/a ou colega de trabalho & $5 \%(23)$ & $4,5 \%(16)$ & $4,8 \%(39)$ \\
\hline consigo mesma (masturbação) & $1,9 \%(9)$ & $0,6 \%(2)$ & $1,3 \%(11)$ \\
\hline outro & $5,6 \%(26)$ & $5,8 \%(21)$ & $5,7 \%(47)$ \\
\hline TOTAL & $100 \%(464)$ & $100 \%(364)$ & $100 \%(828)$ \\
\hline
\end{tabular}

Os valores da tabela são os percentuais em coluna estabelecidos sobre 828 citações.

Fonte: pesquisa "Literatura de autoria feminina brasileira contemporânea: escolhas inclusivas?"

A paridade observada nos números referentes aos grupos sociais com os quais personagens femininas e masculinas se relacionam sexualmente põe em evidência o fato de a literatura contemporânea de mulheres promover fraturas nas "regulações de gênero" problematizadas por Butler (2017) no ensaio assim intitulado. Não se trata, todavia, de a filósofa discutir o modo como o gênero é regulado e a maneira como essas regulações foram impostas, incorporadas e vividas pelos sujeitos generificados sobre os quais elas se impuseram, mas de demonstrar o fato de que os sujeitos femininos e masculinos, respectivamente, oprimidos e opressores ou assujeitados e subjetivados, não existem previamente às regulações, mas, estando sujeitos a elas, são produzidos a partir de e por meio delas mesmas. As regulações de gênero, nesse sentido, partem do pressuposto de que a própria ideia de gênero já implica, por si e a priori, a heterossexualidade compulsória e a subordinação do feminino ao masculino. Daí podermos conjecturar que são as regulações ou normalizações de gênero que conferem inteligibilidade à sexualidade dos sujeitos, partindo do pressuposto de que a 
subordinação heterossexual da mulher a constitui "naturalmente" como alguém que somente deve ter relações sexuais no âmbito do casamento; e o homem, por outro lado, estando no polo da dominação, constituído como alguém mais sexualizado e, portanto, inclinado a vivenciar legitimamente sua sexualidade em múltiplos e concomitantes relacionamentos amorosos.

Na tabela acima, nos deparamos com percentuais de personagens femininas muito próximos aos das masculinas que vivenciam sua sexualidade com amantes (10,8\% e $12,4 \%)$, parceiros/as eventuais ( $8,2 \%$ e $8,8 \%)$, amigos/as, vizinhos/as ou colegas de trabalho ( $5 \%$ e $4,5 \%$, respectivamente), grupos situados em espaços simbólicos que transcendem o solo normalizado e, portanto, sagrado, do casamento civil e da união estável. Quanto a esses últimos, não há, igualmente, diferenças de percentuais que ratifiquem o controle ancestral do poder masculino por meio da representação massiva da sexualidade feminina aí: $28 \%$ e $30,2 \%$ das personagens femininas e masculinas, respectivamente, são representadas vivenciando o sexo no âmbito do casamento civil; e $18,4 \%$ e $18,9 \%$, respectivamente, o vivenciam com a chancela da união estável. O que não significa, obviamente, que essas personagens, tanto as femininas, quanto as masculinas, se limitem às práticas sexuais nos limites dessas instâncias.

Ao cabo de tudo, somos levadas a constatar que as escritoras brasileiras contemporâneas, aqui consideradas, trazem para o universo representacional das relações de gênero práticas corporais que concorrem para a alteração das normas, desconstruindo e desnaturalizando a subordinação sexual das mulheres. Ainda que esses romances não reconfigurem os esquemas tradicionais de sexo-gênerodesejo, já que a maioria das personagens confirma a norma da heterossexualidade, a representação de corpos femininos, todavia, não atualiza a norma da sexualidade feminina vivenciada apenas nos limites do casamento com fins de reprodução. Enquanto aproximadamente $76 \%$ das mulheres representadas tem vida sexual ativa, conforme demonstramos, apenas $40 \%$ delas têm filhos, sinalizando que a prática do sexo, para esse conjunto de personagens, não aparece necessariamente associada à ideia da reprodução e da restrição aos relacionamentos oficializados, como avaliamos acima. Trata-se de dados que concorrem para inscrever a sexualidade dessas mulheres na esfera do desejo e não na dos atos ritualizados. Segundo Butler (2017), as normas nascem desses atos, as quais não possuindo status ontológico independente, só persistem como tais na medida em que são materializadas, reidealizadas e reinstituídas nas e pelas práticas corporais cotidianas. Daí entendermos que o modo de representação da sexualidade dessas mulheres atua como dispositivo de reconfiguração dos papeis de gênero.

Também na realidade empírica tem sido assim: a escuta de mulheres - em entrevistas individuais e em grupos de discussão em que elas explicitam suas experiências, suas ideias, seus sofrimentos e suas esperanças - leva o sociólogo francês Alain Touraine (2007) a defender a tese de que a construção da subjetividade feminina no mundo contemporâneo opera-se, antes de tudo, pela sexualidade e, 
mais amplamente, pelo corpo, espaço de relação consigo e de construção a si. Nas suas palavras, o desejo sexual

transforma-se em relação consigo, em tomada de consciência de si como ser que acima de tudo busca perceber-se e sentir-se como ser desejoso, em dizendo claramente que o mais importante não é a presença do desejo mas a relação consigo mesmo, que acontece através do desejo transformado em construção de si, mediado pela relação amorosa com o outro ou com os outros (p. 56-7).

\section{Últimas considerações: qual, afinal, o retrato do romance brasileiro contemporâneo de autoria feminina?}

No decorrer dos tópicos abordados nas páginas anteriores, estivemos rastreando as notas dominantes do romance brasileiro contemporâneo de autoria feminina, seus focos de interesse, as situações e modos de pensar pinçados da realidade extraliterária e trazidos para o universo representado. E, se são muitos os avanços observados em relação às milenares práticas de opressão feminina, iluminando modos de estar de mulheres em contextos socioculturais feministas, emergidos nesse primeiro vintênio do século, são, igualmente, muitas as ausências sentidas. No retrato do romance brasileiro de mulheres, abstraído a partir desse recorte, não cabe a representatividade sistêmica de diversidades racial, de orientação sexual, de classe, de região, entre outras. Salvo casos isolados, essas não são as principais questões que povoam o imaginário dessas escritoras.

Françoise Collin (2006), filósofa e feminista belga, recorre ao conceito de acosmia para se referir ao fato de que homens e mulheres não dispõem de outros mundos para além do mundo interior e subjetivo que os mesmos expandem em palavras. Mesmo quando essas últimas tomam para si o direito de narrar e, portanto, de escrever literatura, elas permanecem irremediavelmente presas à espécie de cosmos pessoal que lhes institui a visão de mundo, assim como a maneira como o mundo lhes devolve o olhar. E embora a acosmia não seja uma singularidade feminina, de acordo com Collin (2006), ela se apresenta de forma diferente no universo de cada um dos gêneros: para as mulheres, a acosmia se daria por defeito, constituindo, particular e intimista que é, "o mais aqui do mundo", e a dos homens, por excesso, de modo que se difundiria para "além de sua experiência", tomada como exemplo que favoreceria a compreensão do todo universal (p.173). Compreendê-la, todavia, pressupõe a consideração de que o contexto de recepção das obras é, igualmente, diferente para homens e mulheres. A inteligibilidade da acosmia feminina é afetada pelo fato de a cultura dominante não ler as escritoras para além de suas particularidades, encerrando-as nelas mesmas. Aos feminismos contemporâneos caberia impulsionar esse debate ético-político, com a finalidade de dimensionar a inscrição dessas diferenças para além de esquemas redutores de unidade ou de 
dualidade. Nesse contexto, explica a filósofa, a resposta para a pergunta "você escreve como uma mulher?" passa a significar: como você negocia sua posição de mulher e suas experiências femininas em sua escritura? (p.179).

Os dados levantados na pesquisa "Literatura de autoria feminina brasileira contemporânea: escolhas inclusivas?” iluminam o modo como as 91 escritoras, autoras dos 151 romances que lhe constituem o corpus, negociaram no processo de escrita - cada uma a seu modo - a acosmia de que não poderiam se esquivar, vinculada à ideia de identidade feminina. O grande cosmos que se nos apresenta nesses dados é resultante da soma da perspectiva autoral feminina de cada escritora. E se, como dissemos no início dessas reflexões, não se pode negar o fato de, no conjunto, essas escritoras ocuparem um lugar bastante favorável na nossa sociedade, em si, excludente - o que incide no mapa das ausências aí detectado -, é bem verdade também que, no universo representado, as vicissitudes femininas que ocupam as páginas desses romances não dizem respeito apenas às mulheres brancas, de classes elevadas, cultas, moradoras de grandes centros urbanos. Da nossa perspectiva crítica feminista, elas se expandem para questões que permeiam o que poderíamos chamar de núcleo comum das feminilidades.

Até porque, não apenas nessa, mas em diversas outras searas críticas, muito empenho tem sido dispensado para desconstruir as estruturas binárias que historicamente vêm alicerçando as organizações sociais, como é o caso de margens/centro, entre tantas outras. São esforços que, amparados por teorias pósestruturalistas, visam demonstrar que o mundo não é tão dual como se vinha fazendo acreditar.

Sendo assim, as angústias que compõem o cosmos dessas escritoras, se não são as únicas ou as mais prementes nas trajetórias de mulheres de outros grupos sociais, étnicos, regionais, LGBTQ+, não podem ser consideradas só delas, pois não se anulam mediante a interseccionalidade com esses múltiplos eixos de diferenciação, cujos debates no seu entorno vêm movimentando os feminismos contemporâneos e fomentando as discussões acerca do sujeito em nome de quem falam. Em "Não sou uma mulher? Revisitando a Interseccionalidade" (publicado pela primeira vez em 2004), Brah e Phoenix (2017), chamam atenção para o fato de que atributos relativos a 'raça', gênero, sexualidade e classe, entre outros, não sendo esferas distintas e isoladas da experiência, só "passam a existir por e através de relações contraditórias e conflitantes entre si” (p. 671). Os mecanismos de regulação dos gêneros, ainda que assumam diferentes configurações nas diferentes realidades, têm em comum o fato de se constituírem na gênesis da opressão das mulheres - assumam eles a roupagem que for - cerceando-as no direito à sua própria subjetividade, no direito de serem quem, de fato, são e de vivenciarem os valores em que acreditam. Tudo em nome da perpetuação das performances de gênero, compulsoriamente, instituídas e louvacionadas pelas forças hegemônicas de origem patriarcal.

No seu Problemas de Gênero: feminismo e subversão da identidade (2003), Butler adverte que são as performances de gênero, elas mesmas, as responsáveis por 
configurar a ideia do que venha a ser o gênero, embora o sistema obrigue os sujeitos a acreditarem em sua naturalidade. Isso porque não há "nenhuma 'essência' que o gênero expresse ou exteriorize, nem tampouco um ideal objetivo ao qual aspire e porque o gênero não é um dado de realidade" (p. 199). No corpus em questão, as performances femininas representadas a partir da acosmia do recorte autoral referido subvertem, conforme pudemos constatar por meio dos dados quantitativos levantados e dos desdobramentos das principais temáticas, diversos dos mecanismos de regulação do gênero, fazendo emergir novas possibilidades de vivências corporais, as quais vão contrastando com o modelo feminino disseminado pela hegemonia patriarcal.

Tudo ponderado, o retrato do romance brasileiro contemporâneo de autoria feminina, vislumbrado por entre as nuances predominantes em cada um dos itens abordados no decorrer dessa investigação, comporta um considerável rol de subversões feministas, sintetizadas a partir das seguintes recorrências circunscritas no universo representado: 1) predominância de personagens femininas (brancas, de classe média-alta, bonitas, inteligentes, cultas e razoavelmente inseridas no mercado de trabalho); 2) o protagonismo das histórias é predominantemente feminino; 3) as personagens femininas são subjetivadas, imbuídas do direito de falar/narrar e de marcar seu lugar de fala; 4) as mulheres representadas vivenciam a sexualidade para além do duplo e hierarquizado padrão de comportamento generificado; 5) deslocam-se pelos múltiplos espaços domésticos e urbanos disponíveis, assumindo o que podem eles lhes oferecer de conforto e, também, de risco; 6) suas principais demandas são de ordem subjetiva, em que pesam as relações entre o eu e o outro e do eu consigo mesmo; 6) a família, os amores, a sexualidade, a (re)construção identitária, os deslocamentos espaciais, as criminalidades e o fazer literário são as temáticas mais recorrentes na constituição dos enredos.

Se os parâmetros forem os da milenar dominação masculina e o da consequente opressão feminina, não há como negar que esse conjunto de práticas e preocupações que caracterizam o romance contemporâneo escrito por mulheres remete fortemente a subversões feministas e à desconstrução de paradigmas tradicionais de gênero. No entanto, há que se atentar também para o fato de essa produção se afastar, em alguma medida, dos objetivos que vinham marcando a escrita de mulheres ao longo de sua trajetória e, de modo especial, nas últimas décadas do século XX, qual seja, representar e problematizar as diferenças de gênero a partir de um lugar à parte, situado na contramão da ordem das coisas. Num certo sentido, a acosmia feminina predominantemente representada nessas narrativas toma o que chamamos de "subversões feministas" como práticas corriqueiras que se espraiam por entre os enredos, muitas vezes, como pontos pacíficos. Os dualismos reguladores do gênero, pouco são chamados a integrar os conflitos centrais das tramas, embora permeiem as entrelinhas do discurso, como forma de atualizar a história de opressão das mulheres, bem como a das conquistas feministas, ou, ainda, de chamar atenção para heranças reminiscentes da dominação masculina, escamoteadas por entre práticas e ideias aparentemente 
desvinculada dela. Em outras situações, tais dualismos sequer são acionados, de modo que outros interesses e demandas vão se apresentando e ocupando espaço na pauta de discussões que os enredos propiciam.

Ainda assim, tendo em vista a histórica opressão das mulheres e sua (mal) representação ao longo da história literária, e sendo a perspectiva crítica feminista o impulso que nos moveu rumo ao desenvolvimento dessa pesquisa, do mesmo modo que foram os seus operadores de leitura que nos instrumentalizaram em cada uma das etapas empreendidas, a relativização do teor feminista dos atos performáticos que constituem as trajetórias das personagens analisadas não nos parece oportuna. Antes, somos convocadas a iluminar nesse retrato do romance brasileiro contemporâneo de autoria feminina que foi se revelando ao longo desse processo de investigação as subversões feministas a que vimos nos referindo, bem como reconhecer a potência política dessas práticas, não só no sentido de denunciar misoginias remanescentes, mas sobretudo de fixar, via representação, os ganhos já computados.

\section{Referências}

BARBOSA, Maria José Somerlate. Apresentação. Que idade tem a velhice? In:

(Org.). Passo e compasso: nos ritmos do envelhecer. Porto Alegre: EDIPUCRS, 2003.

BORGES FILHO, Ozires. Espaço e literatura: introdução à topoanálise. Franca: Ribeirão Gráfica (2007).

BRAH,Avtar;PHOENIX,Ann. "Nãosouumamulher? RevisitandoaInterseccionalidade”. Tradução de Cláudia Santos Mayer \& Matias Corbett Garcez. In: BRANDÃO, I. et al. Traduções da cultura: perspectivas críticas feministas (1970-2010). Florianópolis: Edufal; Editora da UFSC, 2017.

BUTLER, Judith. Problemas de gênero. Feminismo e subversão da identidade. Rio de Janeiro: Civilização brasileira, 2003.

BUTLER, Judith. "Regulações de gênero" Tradução de Ana Cecília Acioli Lima. In: BRANDÃO, I. et al. Traduções da cultura: perspectivas críticas feministas (1970-2010). Florianópolis: Edufal; Editora da UFSC, 2017.

COLLIN, Françoise. Praxis de la diferencia: liberación y libertad. (edição Marta Segarra). Barcelona: Icária, 2006.

DALCASTAGNÈ, Regina. "A personagem do romance brasileiro contemporâneo: 19902004". Estudos de literatura brasileira contemporânea, 26,13-71, 2005. 
DAMATTA, Roberto. A casa e a rua - espaço, cidadania, mulher e morte no Brasil. Rio de Janeiro: Rocco, 2000.

DUARTE, Constância Lima. Feminismo e literatura no Brasil. Estudos Avançados, Set. /Dec. 2003, vol. 17, no 49, p.151-72. Disponível em: https://www.scielo.br/scielo. php?script=sci_arttext\&pid=So103-40142003000300010\&lng=pt\&tlng=pt. Acesso em 23 de jul. de 20 .

IBGE - Instituto Brasileiro de Geografia e Estatística. Censo demográfico de 2010. Disponível em: <www.ibge.gov.br>. Acesso em: novembro de 2015.

PIZA, Edith (Adolescência e racismo: uma breve reflexão.. In: SIMPOSIO INTERNACIONAL DO ADOLESCENTE, 1., São Paulo, 2005. Disponível em: $<$ http://www.proceedings.scielo.br/scielo.php?script=sci_arttext\&pid=MSCoooooo oo82005000100022\&lng=en\&nrm=abn>. Acesso em 16 de mar. 2020.

RIBEIRO, Djamila. Lugar de fala. Feminismos Plurais. São Paulo: Sueli Carneiro; Pólen, 2019.

SCHMIDT, Rita Terezinha. Para além do dualismo natureza/cultura: ficções do corpo feminino. Organon. Rio Grande do Sul, v. 27, n. 52, 2012. Disponível em: <<http:// seer.ufrgs.br/index.php/organon/article/view/3348o/21353>>. Acesso em 22 de abril de 2020.

TOURAINE, Alain. O mundo das mulheres. Petrópolis: vozes, 2007.

Recebido em 12/12/2020.

Aceito em 01/06/2021. 